\title{
19. The Importance, Development and Reform Challenges of China's Rail Sector
}

Robin Bordie, Stephen Wilson and Jane Kuang ${ }^{1}$

\section{Introduction}

China's rail sector is crucial to the nation and the economy. The first railway was built in China in 1876. Substantial growth occurred in the decades after the establishment of the People's Republic in 1949, and the railway system has become the dominant mode for both passenger and freight transport. Since the beginning of the new millennium, the rapidly increased energy requirements of industrialisation, rising incomes and the increased mobilisation accompanying urbanisation have increased the demands on China's rail system.

In the early to mid 1990s, institutions such as the World Bank, working with the Economic Research Centre (ERC) of the State Planning Commission (SPC), were concerned about the ability of the rail system to transport sufficient coal to meet China's growing demand: 'Since the mid-1980s, China's economic growth has been hampered by shortages of either coal, electricity, or both, due to a shortage of power-generating capacity and the inability to transport enough coal from where it is produced to where it is needed' (ERC 1995:xi). The authors noted that at that time, China was the only country in the world to produce or consume more than 1 billion tonnes of coal in a year - a milestone passed in $1990 .^{2}$ As it turned out, coal demand more than trebled from 1990 to 2010. In 1990, China's railways moved 2.6 billion passenger kilometres. This number had also more than trebled by 2010 .

1 The authors acknowledge research support from their Rio Tinto colleagues Lara Dong, William Wang, Jane Li and Parth Goyal; and valued comments from Dr Wu Jianhong at Beijing Jiaotong University. Any errors are the responsibility of the authors.

2 Only the United States has passed the milestone of 1 billion $t$ of coal production, in seven of the years since 1997, and is currently slightly below that level. The forecasters at the ERC expected this to double to 2 billion $\mathrm{t}$ a year by 2010 . 
No other rail system in the world is asked to move as many people and as great a quantity of goods over such large distances as is China's railway system. No other rail system in the world is as vital as China's to the reliability of national energy supply.

This chapter is written at a time of momentous institutional change for China's rail system, with the dissolution of the former Ministry of Railways (MOR) in 2013, and the establishment of the China Railways Corporation (CRC). The world's largest high-speed rail system is rapidly growing. As China rises through the current middle-income stage, and with the less-developed inland provinces aspiring to follow the development lead of coastal cities and provinces, the rail system will be asked to support even greater demands for the safe, efficient, fast and economical movement of people, energy and goods. The reform of the rail sector, in parallel with the growth and evolution of other parts of the economy, will bring new challenges for policymakers.

This chapter is organised in three main sections and a conclusion. The first section describes the historical context and current situation of the rail sector in China. The second section summarises conditions in 10 countries with significant rail sectors and some attributes that may be of interest for comparison with China's rail sector. The third section describes China's rail reforms and the challenges ahead.

\section{Historical context and the current situation}

\section{Passenger transport}

In 1949, China's railway system transported 103 million passengers, and by 2012 this number had increased by an average rate of 4.6 per cent to more than 1.5 billion (Figure 19.1). Consequently, the passenger transport volume has grown to more than 778 billion passenger kilometres - close to threefold on the 1990 figure of 260 billion passenger km (Figure 19.2). 


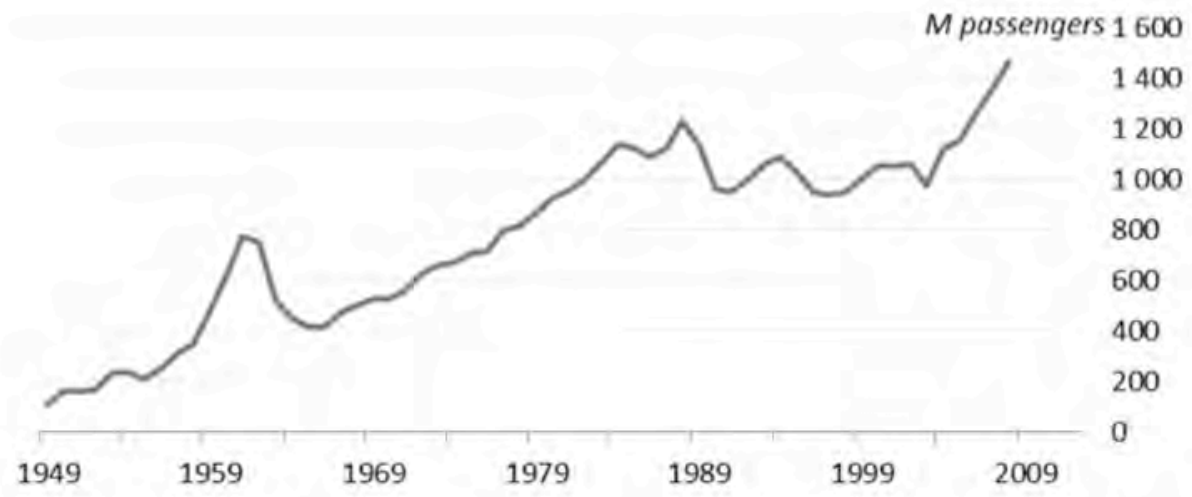

Figure 19.1 China's Railway Passenger Trips, 1949-2008

Source: NBS (2012).

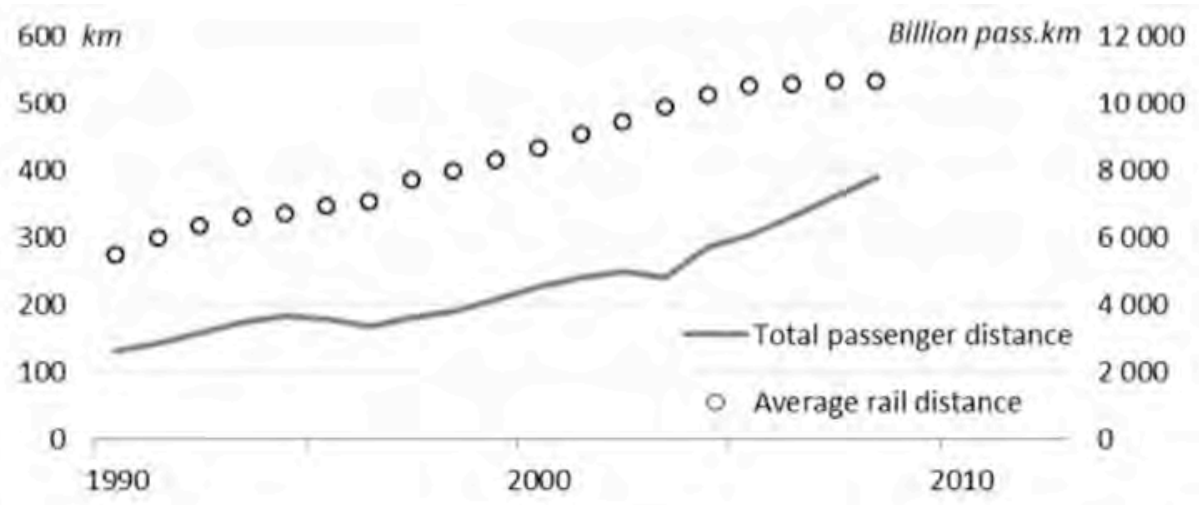

Figure 19.2 Total Passenger Distance Travelled, Average Trip Length, 1990-2008 Source: NBS (2012).

In 1990, 46 per cent of passengers were transported by railway. The proportion had declined to around 34 per cent by 2008 (Figure 19.3). During the same period road transport's share grew from 47 per cent to 54 per cent. Despite the decrease in share, rail remains a dominant and the most efficient passenger transport mode in China. The Spring Festival travel rush, 'Chun Yun', presents the biggest challenge in human history for large-scale annual return visits for people to be with family, generating extremely heavy traffic loads. The period usually begins 15 days before the Lunar New Year's Day and lasts for around 40 days. During the 2014 Spring Festival period, the daily rail passenger demand exceeded 6.5 million passengers and in total more than 266 million passengers travelled by rail during the 40-day period-an increase of 12 per cent on the previous year - and 10 million more passengers than expected. 
Deepening Reform for China's Long-Term Growth and Development

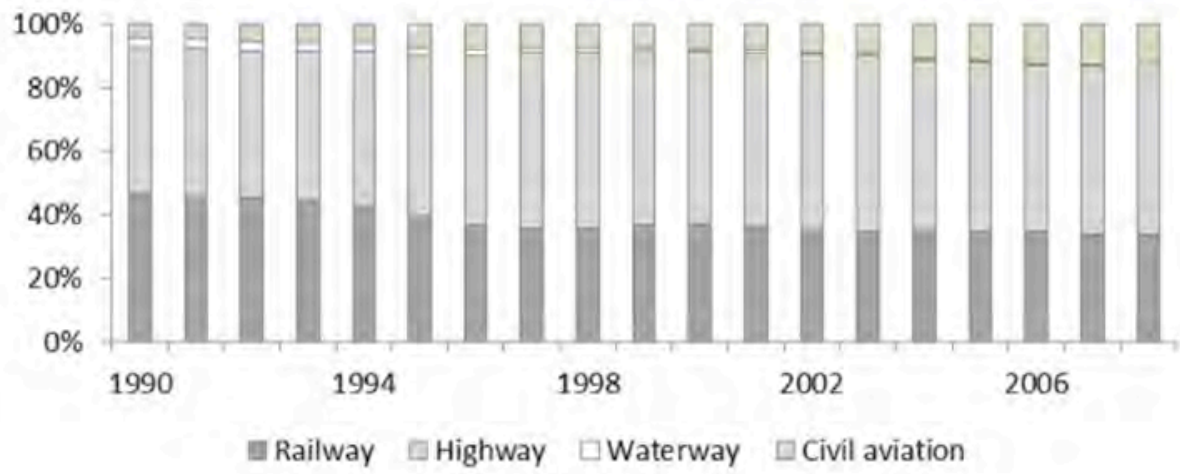

Figure 19.3 Passenger Transport Share by Mode, 1990-2008

Source: NBS (2012).

\section{Freight transport}

The railway system transported 4 billion tonnes (Bt) of goods in 2012 (Figure 19.4), compared with $1.5 \mathrm{Bt}$ in 1990, and less than $2 \mathrm{Bt}$ in 2000. At the same time, freight demand increased from less than 1.4 trillion tonne kilometres (t.km) in 2000 to almost 3 trillion t.km in 2012 (Figure 19.5). Despite the increase of rail freight in absolute terms, however, rail's dominance of the freight market has declined over time. Its share in national freight started to fall from more than 40 per cent in 1978 to just 10 per cent in 2012 (Figure 19.6). At the same time, rail's share of freight tonne kilometres, which was between 70 and 80 per cent in the two decades after 1949, declined to 50 per cent by 1980 and then to less than 20 per cent by 2012 .

Billion t 50

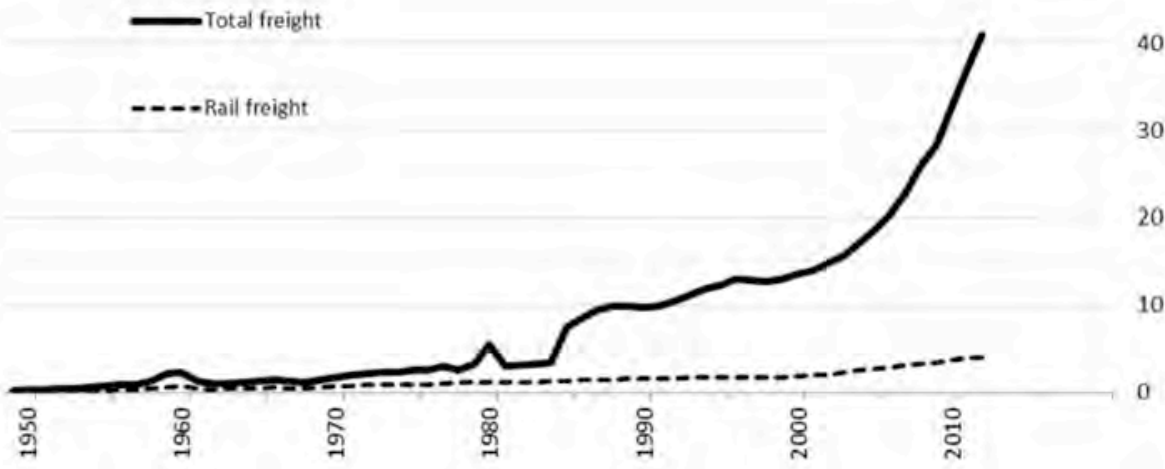

Figure 19.4 Rail Freight Transported

Source: NBS (2012). 


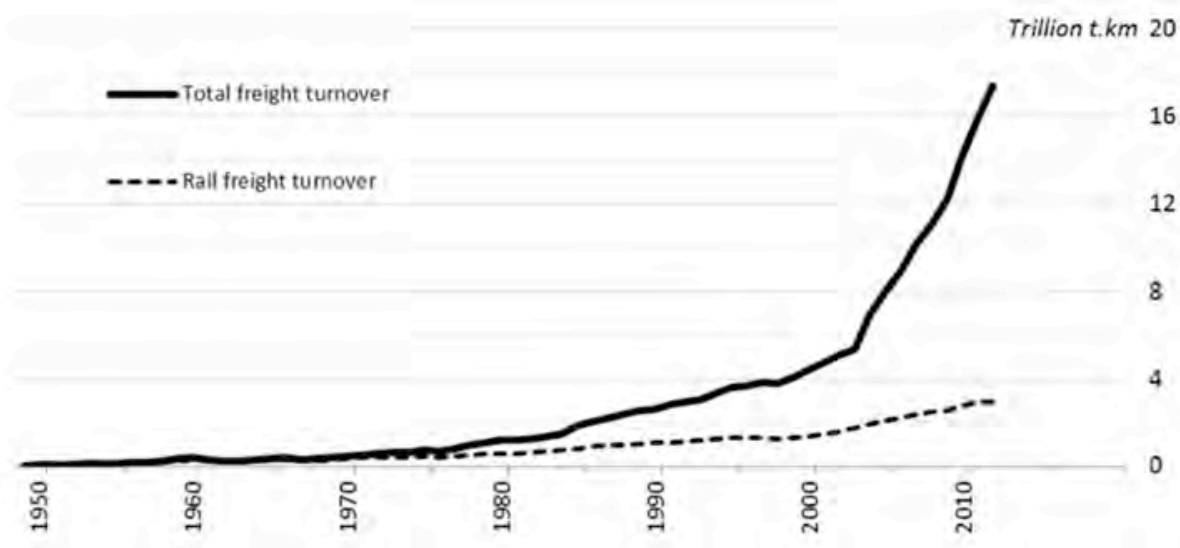

Figure 19.5 Freight Demand: Volume by distance Source: NBS (2012).

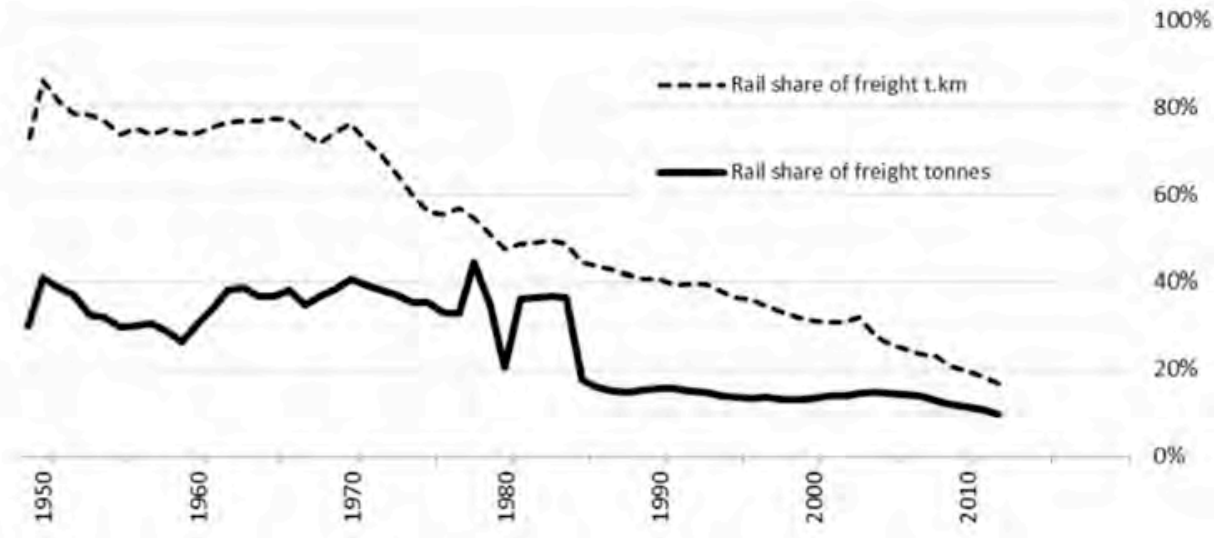

Figure 19.6 Rail Share of Freight and of Total Freight Distances

Source: Authors' calculations based on data from NBS (2012) shown in Figures 19.4 and 19.5.

There was increasing use of cars and trucks, especially for journeys of less than $200 \mathrm{~km}$. Figure 19.7 shows the mean distance for rail freight increased from 400 to $500 \mathrm{~km}$ prior to 1980, and since 1990 has been 700 to $800 \mathrm{~km}$. In comparison, the mean distance for non-rail freight was just 50 to $100 \mathrm{~km}$ prior to 1970 , whereas today it is about $400 \mathrm{~km}$. This is still only about half the distance of the mean rail freight transport haulage. 


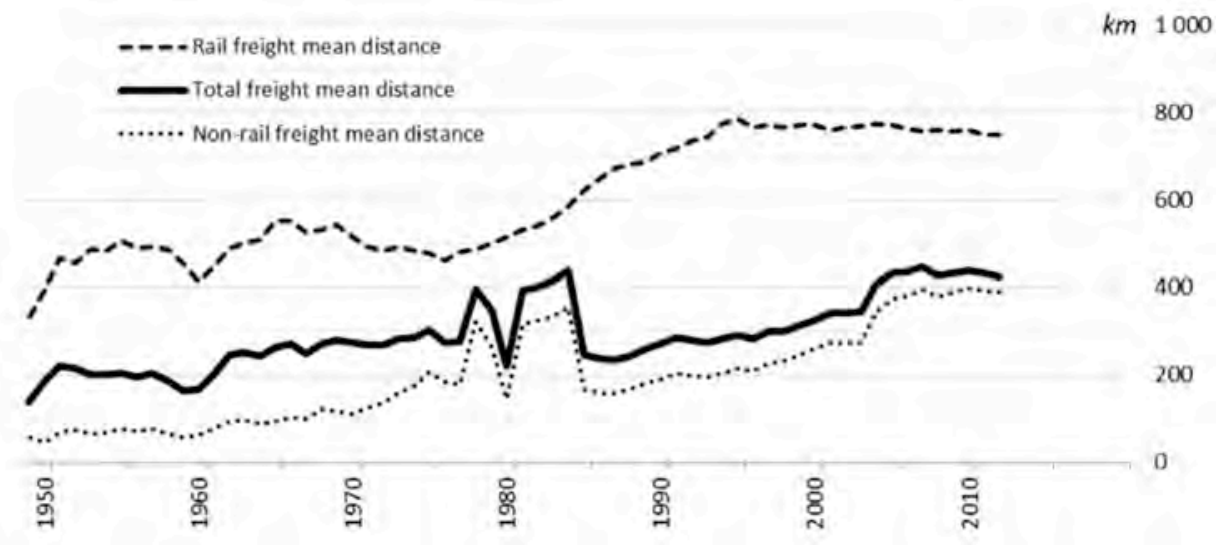

Figure 19.7 Mean Freight Distances

Source: Authors' calculations based on data from NBS (2012) shown in Figures 19.5 and 19.6.

A major factor contributing to this shift has been underinvestment in railway systems over the previous three decades or so, while highway construction has dominated the transport infrastructure investment of the past decade (Figure 19.8).

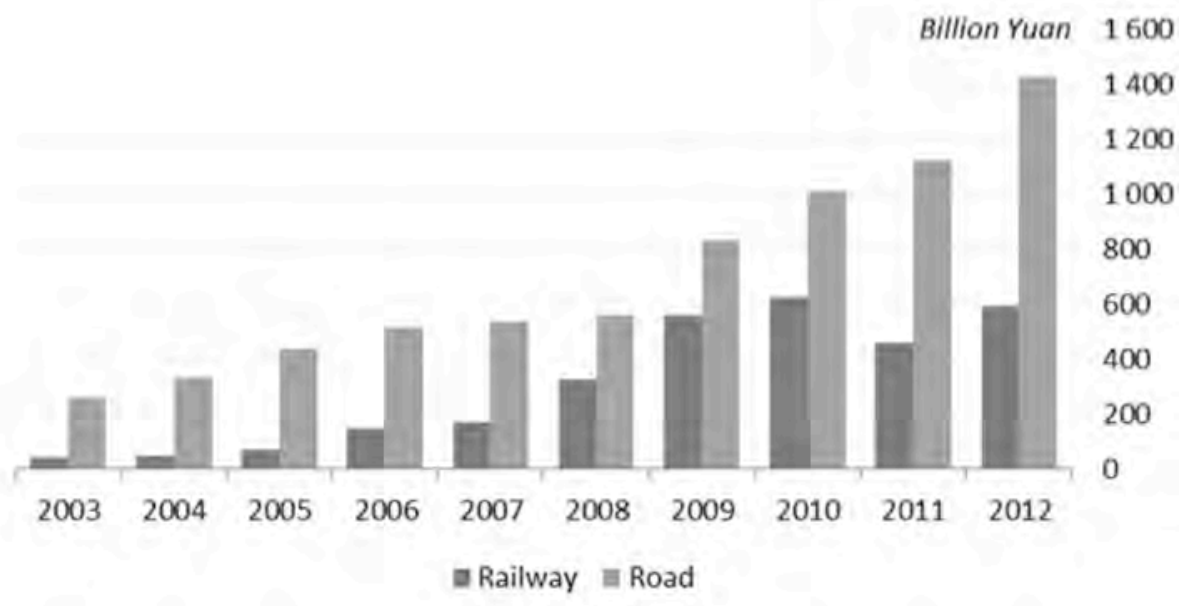

Figure 19.8 Comparison of Rail and Road Investment, 2003-12

Source: NBS (2012).

Figure 19.9 also shows that for the past three and a half decades, the operational length of railway has merely doubled, increasing from $52000 \mathrm{~km}$ in 1978 to $98000 \mathrm{~km}$ by 2012, whereas highway construction, starting from $100 \mathrm{~km}$ in 1988, has expanded exponentially. (China's first highway was built 
between Shanghai and Jiaxing, with a total length of $20 \mathrm{~km}$.) In the two decades to 2012, the operational length of highways increased from almost nothing to equal the length of railways.

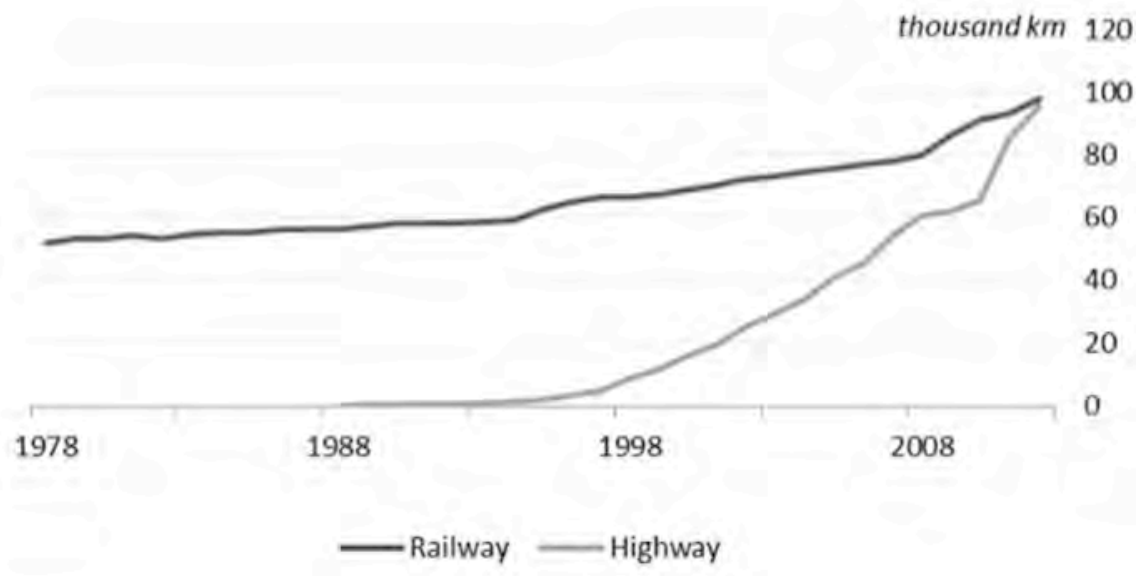

Figure 19.9 Railway and Highway Route Length Compared, 1978-2012

Source: NBS (2012).

The increase in road transport is driven by two main factors. First, China's financial institutions, especially commercial banks, are very willing to lend money for highway construction as they see these projects as low risk and able to generate stable returns via tolls. Second, local governments are very supportive of road development, because they consider these capital-intensive fixed-asset investment projects to be major drivers of local GDP: 'To become rich, construct a road first' has become a popular slogan in China in the past two decades. The available capital and local governments' policy incentives have enabled the massive expansion of China's highway development. In contrast, rail network development has been hindered, with limited availability of finance the major constraint to railway development. Rail financing is discussed further below.

\section{Coal transport}

Although rail is not the dominant freight transport mode, it is nonetheless crucial to China's bulk commodity transport, most importantly to coal- the primary energy source in China. Coal is by far the largest volume cargo type transported on China's railway system. At around $2.3 \mathrm{Bt}$ per annum, coal represents more than half of total freight volume (Figure 19.10). 


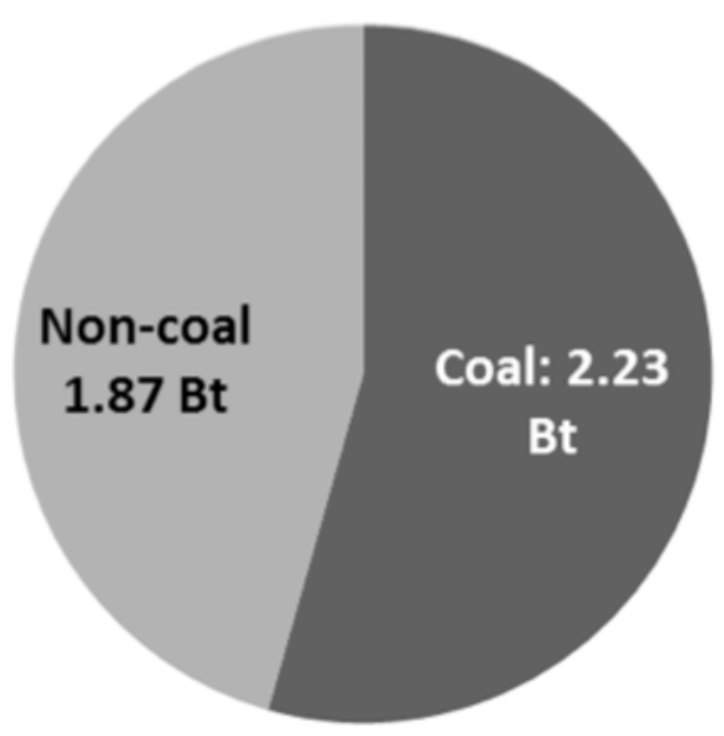

Figure 19.10 Coal and Non-Coal Rail Volumes, 2012 Source: NBS (2012).

The largest capacity coal rail line in the world is the DaQin line belonging to China Rail, transporting more than 400 million $\mathrm{t}(\mathrm{Mt})$ per year between Datong in Shanxi Province and the Qinhuangdao (QHD) port. Shenhua, the world's largest coal producer, with production in 2012 of more than $400 \mathrm{Mt}$ and traded volume of more than $650 \mathrm{Mt}$, owns and operates more than $1500 \mathrm{~km}$ of railway line dedicated to coal transport. Shenhua's case is, however, an exception, as almost all other Chinese coalmines rely on the national railway system for transport, and are hence subject to the centralised capacity planning and 'wagon allocation' system. Of China's annual production of more than $3.5 \mathrm{Bt}$, about 2-2.5 Bt per year of coal is transported by rail, slightly more than the total production of key state-owned enterprises (SOEs) from 21 key provinces. Monthly quantities of coal moved by rail vary, driven by power-coal variability (Figure 19.11). 
$3 B t$

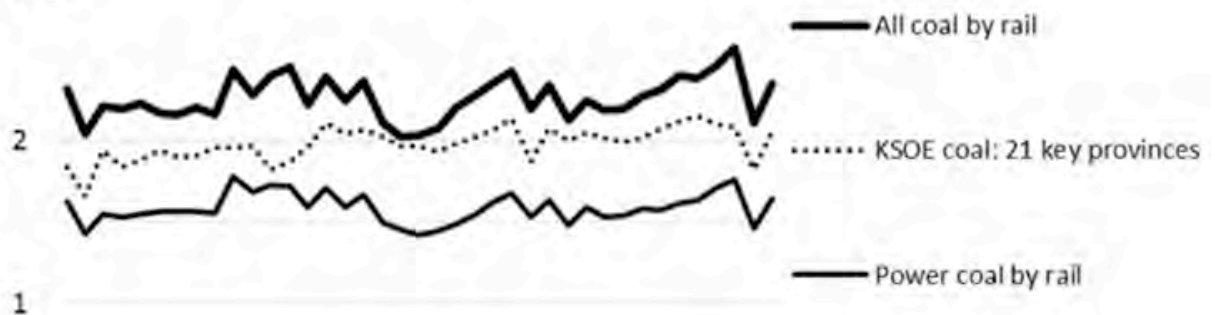

1

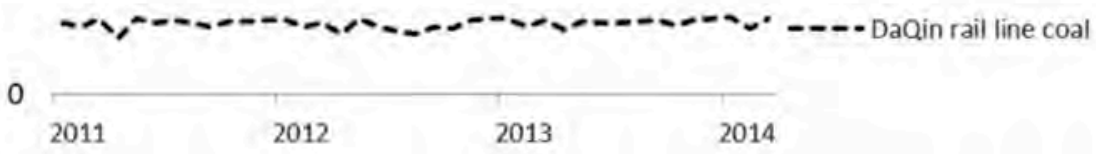

Figure 19.11 China's Monthly Coal Rail Transport Quantities at Annual Rates, January 2011 - March 2014

KSOE $=$ key state-owned enterprises

Sources: NBS (2012); Fenwei/Shanxi Coal (2014).

More than 80 per cent of China's coal is extracted from mines located in the northern and western parts of the country, well away from China's industrial centres along the eastern and southern coasts. The geographical disparity requires large volumes of coal to be transported from inland to the coast over great distances. The major routes are rail to northern ports, QHD and other ports on the rim of the Bohai Sea, and then shipping via coastal freighters to southern ports. There is some southbound rail capacity, but on a per kilometre basis, shipping is considerably cheaper than rail for bulk commodities such as coal. The average coal haul has increased to more than $650 \mathrm{~km}$, reflecting the fact that new mines tend to be located ever further inland and mines closer to the coast tend to be older and subject to closure due to resource depletion, higher costs or safety issues.

The resource-rich regions are usually less economically developed than coastal cities, so consumption in these areas is generally lower. Rail wagons full of coal bound for coastal southern China usually return empty. Lack of 'backhaul' cargoes adversely affects the cost and economic efficiency of the rail system.

Although coal is deemed the commodity of greatest economic importance, its transport is also affected by seasonal variations and other factors - for example, passenger transport priorities - creating pressure in the rail system. Furthermore, wagon dispatch, which is the primary mechanism for allocating scarce capacity in China's rail system, is highly centralised. The rail capacity deficit has not only exacerbated the railway congestion problem, but also made rail capacity allocation for coal a rent-capture opportunity for railway bureaus. 


\section{Ministry of Railways and the China Railway Corporation}

The rail sector is the last of China's large network or infrastructure industries previously organised as government ministries to be reformed. Other network and infrastructure sectors in China that have already been reformed include telecommunications, airlines, power and water, gas and highways. The telecommunications sector operates on a commercial basis, with several leading companies. The airline sector operates on a commercial basis with numerous companies operating domestic and international services. The national highway system continues to be developed, with the extensive (practically universal) use of toll roads. The gas sector is undergoing reform of pricing and network access arrangements as it grows and develops. The former Ministry of Electric Power and Water Resources was restructured, including the separation of generation from transmission and the creation of major generation companies. Electricity prices remain regulated.

Prior to 2013, the Ministry of Railways (MOR) was wholly responsible for the national railway system of both passenger and cargo transport, reporting to the National Development and Reform Commission (NDRC). There were 16 railway bureaus and five railway companies under the MOR, which employed about two million people.

The MOR was both the industry regulator and the operator of almost the entire rail network; it worked with the NDRC on tariff-setting and had the authority to approve the construction of new railway lines shorter than $300 \mathrm{~km}$. Lines longer than $300 \mathrm{~km}$ required approval from the State Council.

Of China's $100000 \mathrm{~km}$ of railway network, more than 80 per cent was owned and operated by the MOR. Only a small proportion is controlled by local authorities, constructed under the sponsorship of local governments serving local needs and providing interconnections with the national railway system.

Reform of the rail sector has proved to be very challenging, as it needs to balance national security, economic efficiency, primary energy transport, social stability and many other factors. Apart from this, the natural monopoly characteristics of the rail sector created vested interests in the very large 'benefit and profit chain', further hindering efforts at reform. Of the three previous major economic reform efforts in China's history - in 1986, 2000 and 2008 - all failed to deliver railway reform, or simply left it for a later time.

That time arrived in early 2013, triggered by a major accident on one of the busiest sections of the new high-speed rail system, the rail sector's debt crisis and the revelation of corruption within the MOR. China Railway Corporation 
(CRC) was established on 14 March 2013 to replace the MOR, reporting to the Ministry of Transport. In the same year, Liu Zhijun, the former Minister of Rail, received a suspended death sentence in the High Court for abuse of power and taking bribes totalling more than $\$ 10$ million in exchange for national railway contracts. The creation of the CRC is the first step towards operation on a commercial basis. After the next section on international comparisons, the final section discusses further China's railway reforms.

\section{Selected international comparisons with China's rail sector}

China is the fourth-largest country in the world by land area, the most populous and the second-largest economy by GDP. China currently ranks third in the world for rail track length. No country is directly comparable with China, and no country's rail sector is directly comparable with China's rail sector. Nevertheless, there are comparable countries for particular characteristics of China and its rail sector.

This section provides 10 international comparators for the Chinese railway sector. These include

- nine of the top 10 countries by rail track length, plus Japan, which ranks eleventh

- eight of the 10 largest economies in the world by GDP at purchasing power parity (PPP), plus Canada and Australia - two resource-rich countries with substantial bulk commodity rail systems

- the seven largest countries by land area, plus Japan, Germany, France and the United Kingdom

- five of the 10 most populous countries in the world, plus Germany, France, the United Kingdom, Canada and Australia.

The selected countries' attributes and points of interest for comparison with China are as follows.

- The United States is the world's largest economy, already developed but comparable in scale with China. The US rail system has almost three times the track length of China. Private monopoly rail systems are used for longdistance coal haulage.

- India has a similar population size to China; it is also an emerging market, using a state-owned rail system for domestic coal movements. The Indian rail system's track length is shorter than China's. 
- Russia has the largest land area of any country in the world, is a former centrally planned socialist economy, has long rail-haul distances, a rail system with very similar track length to China's, is a neighbouring country and an export supplier to the international coal market.

- Brazil is a large country, with the fifth-largest land area, the fifth-largest population, an emerging market with the seventh-largest economy in the world and with a bulk rail system - notably, for iron ore - with the tenthlargest rail track length of any country in the world.

- Canada has the second-largest land area in the world, a small population and a medium-sized developed economy. Canada has the fifth-longest rail system in the world and some similarities to Australia. Canada does move coal on rails and may have lessons for China.

- Australia has substantial coal and iron ore resources, which are relatively close to the coast, but still require rail systems several hundred kilometres long for their efficient delivery to export ports. Coal in New South Wales and Queensland on the east coast is delivered to port via multi-user rail systems. In New South Wales, coal from the Hunter Valley also shares the rails with small passenger trains, impacting efficiency. Iron ore in the Pilbara region of Western Australia is delivered to ports via highly efficient private proprietary dedicated bulk rail systems.

- Japan is seen as a leader, particularly for its high-speed passenger system, which China is emulating with China Railway High-speed (CRH). Japan's coal is all imported and used in coastal power plants and steel mills, so Japan does not have China's enormous coal rail transport challenges.

- Germany is generally considered to be a model of industrial efficiency. Germany moves a lot of coal by river barge, and has an extensive rail system, with the world's sixth-longest track length. Germany's rail system is far more dense than Japan's in terms of track length per square kilometre.

- France is also seen as a leader in high-speed passenger rail, with the TGV system, but with the dominance of nuclear power is not a major coal consumer.

- The United Kingdom was the global pioneer in commercialising railways in the nineteenth century. Since then, the United Kingdom has tried almost all rail sector models, from private to nationalised, back to private and now a hybrid of state and private ownership. While mostly about passenger rail, the United Kingdom's recent experience demonstrates the complexity of rail sector reform and regulation.

Table 19.1 summarises key characteristics of China and the 10 selected comparator countries. 
Table 19.1 Summary Overview of the Rail Sector of China and 10 International Comparators

\begin{tabular}{|c|c|c|c|c|c|c|}
\hline Country & $\begin{array}{c}\text { Land area } \\
\text { (million sq } \\
\mathrm{km} \text { ) }\end{array}$ & $\begin{array}{c}\text { Population } \\
\text { (millions) }\end{array}$ & $\begin{array}{c}\text { First rail } \\
\text { (year) }\end{array}$ & $\begin{array}{c}\text { Track } \\
\text { length } \\
(\text { '000 km) }\end{array}$ & $\begin{array}{c}\text { Current rail } \\
\text { companies } \\
\text { (No.) }\end{array}$ & $\begin{array}{c}\text { Ownership } \\
\text { (type) }\end{array}$ \\
\hline China & $\begin{array}{l}9.60 \\
\text { No. } 4\end{array}$ & $\begin{array}{l}1349 \\
\text { No. } 1\end{array}$ & $\begin{array}{c}1876 \\
\text { No. } 10\end{array}$ & $\begin{array}{l}98 * \\
\text { No. } 2\end{array}$ & 2 & State* \\
\hline United States & $\begin{array}{l}9.83 \\
\text { No. } 3\end{array}$ & $\begin{array}{c}317 \\
\text { No. } 3\end{array}$ & $\begin{array}{r}1828 \\
\text { No. } 2\end{array}$ & $\begin{array}{c}228 \\
\text { No. } 1\end{array}$ & Many & Private \\
\hline India & $\begin{array}{l}3.29 \\
\text { No. } 7\end{array}$ & $\begin{array}{l}1220 \\
\text { No. } 2\end{array}$ & $\begin{array}{l}1853 \\
\text { No. } 7\end{array}$ & $\begin{array}{c}64 \\
\text { No. } 4\end{array}$ & 1 & State \\
\hline Russia & $\begin{array}{c}17.1 \\
\text { No. } 1\end{array}$ & $\begin{array}{c}142 \\
\text { No. } 9\end{array}$ & $\begin{array}{r}1837 \\
\text { No. } 6\end{array}$ & $\begin{array}{c}84 \\
\text { No. } 3\end{array}$ & 1 & State \\
\hline Brazil & $\begin{array}{l}8.51 \\
\text { No. } 5\end{array}$ & $\begin{array}{l}201 \\
\text { No. } 5\end{array}$ & $\begin{array}{r}1854 \\
\text { No. } 8\end{array}$ & $\begin{array}{c}30 \\
\text { No. } 10\end{array}$ & 12 & Private \\
\hline Canada & $\begin{array}{c}9.98 \\
\text { No. } 2\end{array}$ & $\begin{array}{c}35 \\
\text { No. } 37\end{array}$ & $\begin{array}{r}1836 \\
\text { No. } 5\end{array}$ & $\begin{array}{c}52 \\
\text { No. } 5\end{array}$ & Many & Private \\
\hline Australia & $\begin{array}{l}7.74 \\
\text { No. } 6\end{array}$ & $\begin{array}{c}22 \\
\text { No. } 55\end{array}$ & $\begin{array}{l}1831 \\
\text { No. } 3\end{array}$ & $\begin{array}{c}38 \\
\text { No. } 7\end{array}$ & Several & Mixed \\
\hline Germany & $\begin{array}{c}0.357 \\
\text { No. } 63\end{array}$ & $\begin{array}{c}81 \\
\text { No. } 16\end{array}$ & $\begin{array}{l}1831 \\
\text { No. } 3\end{array}$ & $\begin{array}{c}33 \\
\text { No. } 6\end{array}$ & Many & Mixed \\
\hline Japan & $\begin{array}{c}0.378 \\
\text { No. } 62\end{array}$ & $\begin{array}{c}127 \\
\text { No. } 10\end{array}$ & $\begin{array}{r}1872 \\
\text { No. } 9\end{array}$ & $\begin{array}{c}20 \\
\text { No. } 10\end{array}$ & Many & Mixed \\
\hline France & $\begin{array}{c}0.644 \\
\text { No. } 43\end{array}$ & $\begin{array}{c}66 \\
\text { No. } 21\end{array}$ & $\begin{array}{l}1832 \\
\text { No. } 4\end{array}$ & $\begin{array}{c}30 \\
\text { No. } 8\end{array}$ & 1 & State \\
\hline $\begin{array}{l}\text { United } \\
\text { Kingdom }\end{array}$ & $\begin{array}{c}0.244 \\
\text { No. } 80\end{array}$ & $\begin{array}{c}63 \\
\text { No. } 22\end{array}$ & $\begin{array}{l}1807 \\
\text { No. } 1\end{array}$ & $\begin{array}{c}16 \\
\text { No. } 11\end{array}$ & Many & Mixed \\
\hline
\end{tabular}

* Two 'private' coal rail lines are owned and operated by Shenhua, which is also a state-owned enterprise. Source: World Bank (2013).

Note: By 2012, China ranked second after the United States - total operational rail track length had reached $98000 \mathrm{~km}$.

Table 19.2 provides further detail on the ownership, industry structure, key companies, legislation, and the form of economic regulation and identity of the independent regulator, if there is one, for China and the 10 comparator countries. 
Table 19.2 Railway Industry Structures and their Interactions with Ownership, Regulation and Competition

\begin{tabular}{|c|c|c|c|c|c|}
\hline & China & United States & India & Russia & Brazil \\
\hline $\begin{array}{l}\text { Sector } \\
\text { structure }\end{array}$ & $\begin{array}{l}\text { Vertical } \\
\text { integration }\end{array}$ & $\begin{array}{l}\text { Tenant } \\
\text { operators }\end{array}$ & $\begin{array}{l}\text { Vertical } \\
\text { integration }\end{array}$ & $\begin{array}{l}\text { Vertical } \\
\text { integration }\end{array}$ & $\begin{array}{l}\text { Tenant } \\
\text { operators }\end{array}$ \\
\hline $\begin{array}{l}\text { Ownership of } \\
\text { railways }\end{array}$ & Public & $\begin{array}{l}\text { Private } \\
\text { companies }\end{array}$ & Public & Public & $\begin{array}{l}\text { Private } \\
\text { companies }\end{array}$ \\
\hline $\begin{array}{l}\text { Main } \\
\text { company }\end{array}$ & $\begin{array}{l}\text { China } \\
\text { Railways } \\
\text { Corporation }\end{array}$ & $\begin{array}{l}8 \text { major private } \\
\text { companies }\end{array}$ & $\begin{array}{l}\text { Indian } \\
\text { Railways }\end{array}$ & JSC RZD & $\begin{array}{l}8 \text { major } \\
\text { companies } \\
\text { after } \\
\text { privatisation } \\
\text { in } 1998\end{array}$ \\
\hline $\begin{array}{l}\text { Other } \\
\text { companies }\end{array}$ & $\begin{array}{l}\text { Shenhua: two } \\
\text { coal rail lines }\end{array}$ & $\begin{array}{l}338 \text { Class I, } \\
16 \text { Class II, + } \\
\text { others }\end{array}$ & None & None & 4 \\
\hline $\begin{array}{l}\text { Number of } \\
\text { companies }\end{array}$ & $\begin{array}{l}2+16 \\
\text { subsidiary } \\
\text { bureaus and } 5 \\
\text { companies }\end{array}$ & $\sim 630$ & 1 & 1 & 12 \\
\hline $\begin{array}{l}\text { Key } \\
\text { legislation }\end{array}$ & $\begin{array}{l}\text { Railway Law } \\
\text { (1991) }\end{array}$ & $\begin{array}{l}\text { Staggers Rail } \\
\text { Act }(1980)\end{array}$ & $\begin{array}{l}\text { The } \\
\text { Railways } \\
\text { Act (1989) }\end{array}$ & $\begin{array}{l}\text { Federal Law } \\
\text { on Railway } \\
\text { Transport in } \\
\text { the Russian } \\
\text { Federation } \\
(2003)\end{array}$ & n.a. \\
\hline $\begin{array}{l}\text { Structural } \\
\text { separation/ } \\
\text { regulation }\end{array}$ & $\begin{array}{l}\text { Yes. } 2013 \\
\text { corporatisation }\end{array}$ & $\begin{array}{l}\text { Light. Trackage } \\
\text { rights exist } \\
\text { (Amtrak) }\end{array}$ & None & $\begin{array}{l}\text { Light. } 2003 \\
\text { restructuring }\end{array}$ & $\begin{array}{l}\text { Management } \\
\text { by } \\
\text { companies; } \\
\text { trackage } \\
\text { rights exist }\end{array}$ \\
\hline $\begin{array}{l}\text { Economic } \\
\text { regulator }\end{array}$ & $\begin{array}{l}\text { NDRC as } \\
\text { notionally } \\
\text { independent } \\
\text { rail freight } \\
\text { tariff and } \\
\text { passenger fare } \\
\text { regulator }\end{array}$ & $\begin{array}{l}\text { US } \\
\text { Department of } \\
\text { Transportation } \\
\text { and the } \\
\text { Surface } \\
\text { Transportation } \\
\text { Board }\end{array}$ & $\begin{array}{l}\text { None: } \\
\text { direct } \\
\text { control } \\
\text { of the } \\
\text { ministry }\end{array}$ & $\begin{array}{l}\text { MOT and } \\
\text { MEDT; Federal } \\
\text { Antimonopoly } \\
\text { Service } \\
\text { and Federal } \\
\text { Service for } \\
\text { Tariffs }\end{array}$ & $\begin{array}{l}\text { Agência } \\
\text { Nacional de } \\
\text { Transportes } \\
\text { Terrestres } \\
\text { (ANTT) }\end{array}$ \\
\hline $\begin{array}{l}\text { Form of } \\
\text { economic } \\
\text { regulation }\end{array}$ & $\begin{array}{l}\text { Price } \\
\text { regulation: } \\
\text { end charges to } \\
\text { users }\end{array}$ & $\begin{array}{l}\text { Price freedom } \\
\text { and closures } \\
\text { of loss-making } \\
\text { lines }\end{array}$ & $\begin{array}{l}\text { Price } \\
\text { regulation: } \\
\text { end } \\
\text { charges to } \\
\text { users }\end{array}$ & $\begin{array}{l}\text { Price } \\
\text { regulation. } \\
\text { Passenger } \\
\text { service: end } \\
\text { charges to } \\
\text { users } \\
\text { Freight } \\
\text { service: tariff } \\
\text { cap }\end{array}$ & $\begin{array}{l}\text { Price } \\
\text { regulation }\end{array}$ \\
\hline Competition* & $\begin{array}{l}\text { Intermodal } \\
\text { only }\end{array}$ & $\begin{array}{l}\text { Intermodal and } \\
\text { limited intra- } \\
\text { modal }\end{array}$ & $\begin{array}{l}\text { Intermodal } \\
\text { only }\end{array}$ & $\begin{array}{l}\text { Intermodal } \\
\text { only }\end{array}$ & $\begin{array}{l}\text { Intermodal } \\
\text { and limited } \\
\text { intra-modal }\end{array}$ \\
\hline
\end{tabular}




\begin{tabular}{|c|c|c|c|c|c|}
\hline Canada & Australia & Germany & Japan & France & \begin{tabular}{|l|} 
United \\
Kingdom
\end{tabular} \\
\hline \begin{tabular}{|l|} 
Tenant \\
operators
\end{tabular} & $\begin{array}{l}\text { Competitive } \\
\text { access }\end{array}$ & $\begin{array}{l}\text { Competitive } \\
\text { access }\end{array}$ & \begin{tabular}{|l|} 
Tenant \\
operators
\end{tabular} & \begin{tabular}{|l} 
Vertical \\
integration
\end{tabular} & $\begin{array}{l}\text { Competitive } \\
\text { access }\end{array}$ \\
\hline $\begin{array}{l}\text { Private } \\
\text { companies }\end{array}$ & Mixed & Mixed & $\begin{array}{l}\text { Mixed. Japan } \\
\text { National } \\
\text { Railways } \\
\text { privatised } \\
\text { in } 1987\end{array}$ & Public & $\begin{array}{l}\text { Private } \\
\text { companies }\end{array}$ \\
\hline $\mathrm{CN}$ and $\mathrm{CP}$ & $\begin{array}{l}5 \text { major } \\
\text { companies } \\
\text { ( } 1 \text { federal and } \\
4 \text { state-owned } \\
\text { companies) }\end{array}$ & $\begin{array}{l}1 \text { major } \\
\text { private } \\
\text { company }\end{array}$ & \begin{tabular}{|l} 
Japan \\
Railways (7 \\
subsidiaries)
\end{tabular} & $\begin{array}{l}\text { SNCF (6 } \\
\text { subsidiaries) }\end{array}$ & $\begin{array}{l}3 \text { major } \\
\text { companies }\end{array}$ \\
\hline $\begin{array}{l}50+\text { regional } \\
\text { and short-line } \\
\text { carriers }\end{array}$ & 18 & $\begin{array}{l}160 \text { big } \\
\text { freight/ } \\
\text { passenger } \\
\text { companies + } \\
\text { others }\end{array}$ & $\begin{array}{l}16 \text { major } \\
\text { private } \\
\text { companies; } \\
6 \text { semi- } \\
\text { major private } \\
\text { companies; } \\
83 \text { others }\end{array}$ & 4 & $\begin{array}{l}26 \text { train } \\
\text { operating } \\
\text { companies } \\
7 \text { freight } \\
\text { operating } \\
\text { companies }\end{array}$ \\
\hline$\sim 82$ & 23 & $\sim 1500$ & $\sim 112$ & 5 & 36 \\
\hline $\begin{array}{l}\text { Canadian } \\
\text { Transportation } \\
\text { Act (1996) }\end{array}$ & \begin{tabular}{|l|} 
Australian \\
National \\
Railways \\
Commission Act \\
(1983)
\end{tabular} & $\begin{array}{l}\text { General } \\
\text { Railway Act } \\
\text { (2005) }\end{array}$ & \begin{tabular}{|l} 
Railway \\
Business Act \\
(1986)
\end{tabular} & $\begin{array}{l}\text { Regulation } \\
\text { of Railway } \\
\text { Transport } \\
\text { (2009) }\end{array}$ & $\begin{array}{l}\text { The } \\
\text { Railways } \\
\text { Act (2005) }\end{array}$ \\
\hline \begin{tabular}{|l|} 
Light \\
regulation
\end{tabular} & Light regulation & $\begin{array}{l}\text { Light } \\
\text { regulation }\end{array}$ & \begin{tabular}{|l|} 
Restructuring \\
in 1990s
\end{tabular} & $\begin{array}{l}\text { Light } \\
\text { regulation }\end{array}$ & $\begin{array}{l}\text { Heavy } \\
\text { regulation: } \\
\text { total } \\
\text { separation } \\
\text { after } \\
\text { restructuring } \\
\text { in } 1994\end{array}$ \\
\hline $\begin{array}{l}\text { Canadian } \\
\text { Transportation } \\
\text { Agency (CTA) }\end{array}$ & $\begin{array}{l}\text { State-specific } \\
\text { independent } \\
\text { regulators } \\
\text { for essential } \\
\text { services } \\
\text { including } \\
\text { railways }\end{array}$ & \begin{tabular}{|l|} 
German \\
Federal \\
Railway \\
Authority \\
(Eisenbahn- \\
Bundesamt, \\
EBA and \\
Bundesländer)
\end{tabular} & $\begin{array}{l}\text { No } \\
\text { independent } \\
\text { regulator; } \\
\text { direct control } \\
\text { of Railways } \\
\text { Bureau, } \\
\text { Ministry } \\
\text { of Land, } \\
\text { Infrastructure, } \\
\text { Transport and } \\
\text { Tourism }\end{array}$ & $\begin{array}{l}\text { Regulatory } \\
\text { Authority } \\
\text { for Railway } \\
\text { Activities }\end{array}$ & $\begin{array}{l}\text { Office } \\
\text { of Rail } \\
\text { Regulation } \\
\text { (ORR) }\end{array}$ \\
\hline Revenue cap & \begin{tabular}{|l|} 
Third-party \\
access to \\
national and east \\
coast multi- \\
user systems. \\
Dedicated \\
private bulk \\
systems in \\
Western \\
Australia \\
\end{tabular} & $\begin{array}{l}\text { Price } \\
\text { regulation: } \\
\text { terms of user } \\
\text { access }\end{array}$ & $\begin{array}{l}\text { Yardstick } \\
\text { competition }\end{array}$ & $\begin{array}{l}\text { Price } \\
\text { regulation }\end{array}$ & $\begin{array}{l}\text { Fixed track } \\
\text { access } \\
\text { charges }+ \\
\text { regulated } \\
\text { track and } \\
\text { station } \\
\text { access } \\
\text { charge }\end{array}$ \\
\hline $\begin{array}{l}\text { Intermodal and } \\
\text { limited intra- } \\
\text { modal }\end{array}$ & $\begin{array}{l}\text { Intermodal and } \\
\text { intra-modal }\end{array}$ & $\begin{array}{l}\text { Intermodal } \\
\text { and intra- } \\
\text { modal }\end{array}$ & $\begin{array}{l}\text { Intermodal } \\
\text { and some } \\
\text { intra-modal }\end{array}$ & $\begin{array}{l}\text { Intermodal } \\
\text { only }\end{array}$ & $\begin{array}{l}\text { Intermodal } \\
\text { and intra- } \\
\text { modal }\end{array}$ \\
\hline
\end{tabular}

MOT $=$ Ministry of Transport

MEDT $=$ Ministry of Economic Development and Trade

* Intermodal competition is assumed to be present everywhere. 
The 1980s generally saw a steady loss of market share for railways globallyoutcompeted by various alternative modes of transportation. As car ownership rose with disposable incomes, the convenience of private road transport took market share from passenger rail services over shorter distances, while the speed of air travel saw it take market share over longer distances. National rail companies incurred heavy losses, which were financed by public subsidies in many countries. In the freight sector, loading and unloading efficiencies and door-to-door service enabled trucking to take market share from rail. These intermodal competitive pressures created an imperative for revival of the 'productivity and profitability' of the respective rail companies through a process of reform and restructuring.

The next sections discuss the differences and similarities of China's railway sector in comparison with other international economies, and its areas of uniqueness.

\section{China's profile in the global rail industry}

China today has the second-largest railway network in the world, behind only the United States, having overtaken Russia in 2009. In terms of passenger transport, China has a high population density in settled areas and about 160 cities of more than one million people. A growing inclination to travel, and the construction of the world's largest high-speed rail network, is driving the largest-scale and most intense intercity rail passenger flows in the world.

With regards to freight transport, China's economy relies heavily on high volume, long-distance movements of coal, metal ores, iron and steel and other bulk products. In particular, movement of coal by rail is crucial to the economy, as coal generates about three-quarters of China's electricity and provides about two-thirds of its primary energy.

Considering passenger and freight traffic together, China's railway system is one of the busiest in the world, with the highest traffic density (million traffic units per route kilometres) in 2011 (Figure 19.12). Railway systems in the United States, Canada, Australia and Brazil are dominated by freight movement with very minimal passenger traffic. 


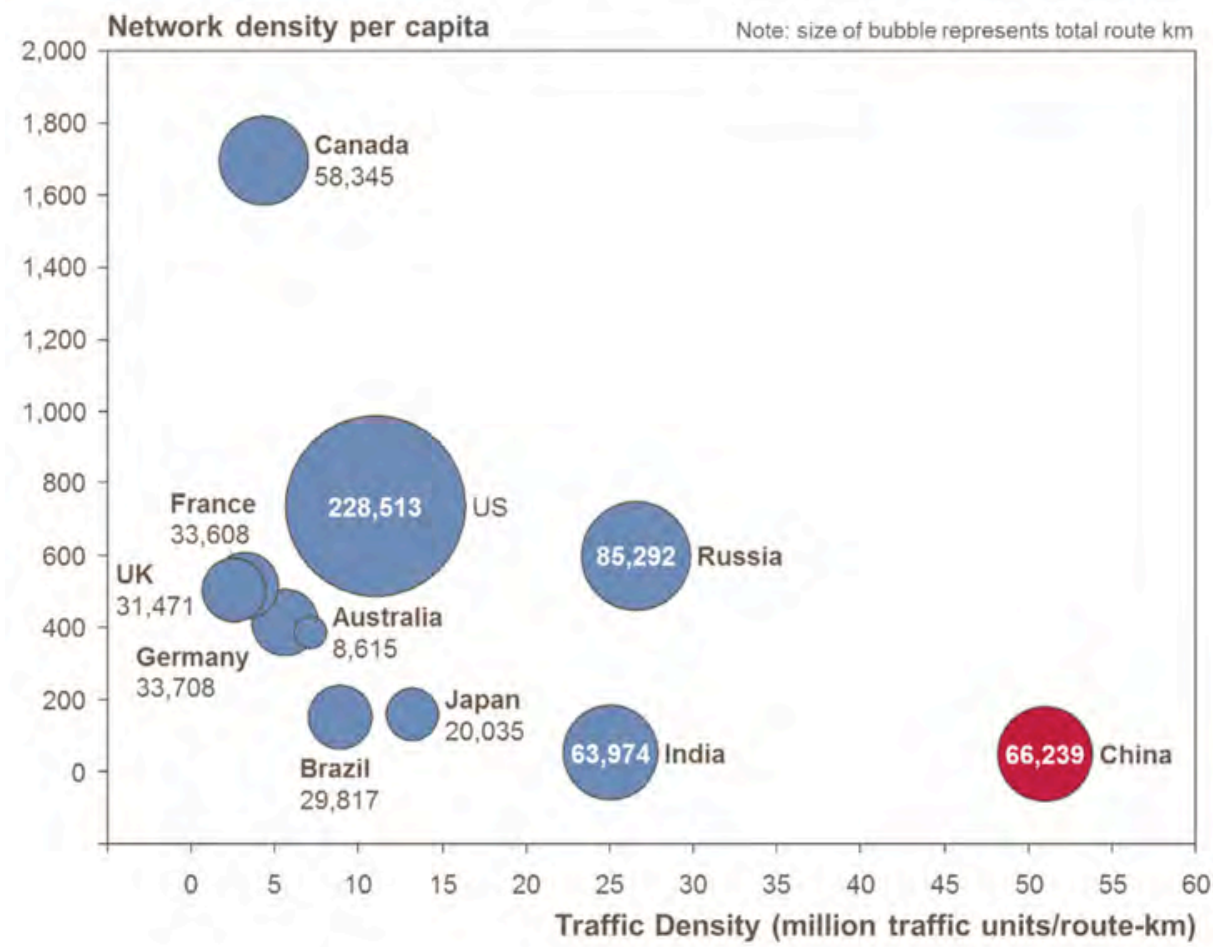

Figure 19.12 Global Comparison of Rail Systems

Source: Authors' analysis using data from The World Bank database.

Even though China has seen a rapid increase in the size of its rail system, its network density per capita (measured as route kilometres per million people) is one of the lowest in the world - similar to India's. China's rail infrastructure is so heavily used that in 2011 it carried 27 per cent of the world's rail traffic on around 7 per cent of the world's rail network.

\section{Railway regulation in global context}

This section identifies similarities and differences in the regulatory and institutional structures of 11 countries that collectively carry 90 per cent of the total long-distance rail traffic in the world - that is, excluding urban mass transit systems. ${ }^{3}$

Apart from India, all the other countries have a comparable transport ministry at the central government level that aims to promote the public interest across all modes of transport. The transport ministry in all these countries has

3 Authors' estimates. China also has and is extending large mass transit systems, but they are beyond the scope of this chapter. 
a public policy agenda to integrate the national railways with other modes of transportation. Before March 2013, China had the independent MOR, which was responsible for developing and administering policies for the railway sector as well as owning and operating the rail system. The dissolution of China's MOR has ensured that the role of policymaking and regulation is now separated from asset ownership and service delivery. This is a significant landmark in the history of China's railways, as the separation is likely to facilitate more efficient forms of organisation for the service providers.

All comparator countries have undergone some form of structural reforms in their railway sectors. The railways in the United States and Canada began with private investment in the late 1800s. After a short period of nationalisation, both economies today have completely privatised railway systems.

The 1990s saw the introduction of competitive access in Japan and Australia, as they moved towards partial privatisation of their national railways. During the same period, rail industries in Germany and the United Kingdom introduced various models of vertical separation through privatisation by separating the roles of infrastructure management from service delivery. Structured rail reforms in Russia and Brazil introduced privatisation to the national railways during the early years of the twenty-first century. China and India, unlike other countries, have so far refrained from major reforms to their railway sectors - the reasons for which are well documented. In recent years, China has allowed a number of dedicated coal freight lines. Sometimes called 'private rail lines' in China, as they are not wholly owned by the former MOR or its successor, the $\mathrm{CRC}$, these are more correctly referred to as 'jointly owned rail lines'. Shenhua holds the controlling interest and operation rights, while CRC and other local companies hold the remaining interest.

All countries except India and France now have a defined corporate structure distinct from government. While distinctions across ownership exist (state versus private), corporate structure allows for competition and productivity gains. In the case of China, the recently established state-owned CRC is responsible for operating commuter and freight transport via subsidiary companies. The national rail operator in France, SNCF, while not a corporation, is a state-owned railway company that operates under its own legislation. In India, the Ministry of Railways continues to single-handedly operate the state-owned monopoly, Indian Railways. Institutional governance and regulatory regimes for the rail industries of the 11 countries are depicted in the matrix below (Figure 19.13). 


\section{Framework for analysis of ownership structures and regulatory approaches}

Historically, rail transportation in many countries has been perceived to be a public good or a form of social service, irrespective of its complexity and profitability. Rail networks tended to be viewed as having strong natural monopoly characteristics. State ownership is a common remedy to the natural monopoly problem, but other models are possible. In this chapter, we adopt a two-axis categorisation, providing a matrix framework for the various models of organisational structures and regulation of railways around the world (Figure 19.13).

On one axis we consider the ownership of the rail sector, distinguishing stateowned from privately owned rail systems, and acknowledging that in some countries there is a mix of the two, whether from one region of the country to another, for different systems (for example, freight and passenger), different parts of the sector (for example, the tracks 'below rail' and the rolling stock 'above rail'), or through partial floats of shares in companies.

On the other axis we consider the regulation of the industry. We note that models exist where there is either no formal regulation (of private rail companies) or no notion of a separation between the ownership of rail assets and their regulation - for example, where a self-regulating government ministry owns the assets. So, the regulation axis includes the concept of regulatory separation between the ownership of the rail sector assets and their regulation, distinguishing no separation, from light regulation and heavy regulation.
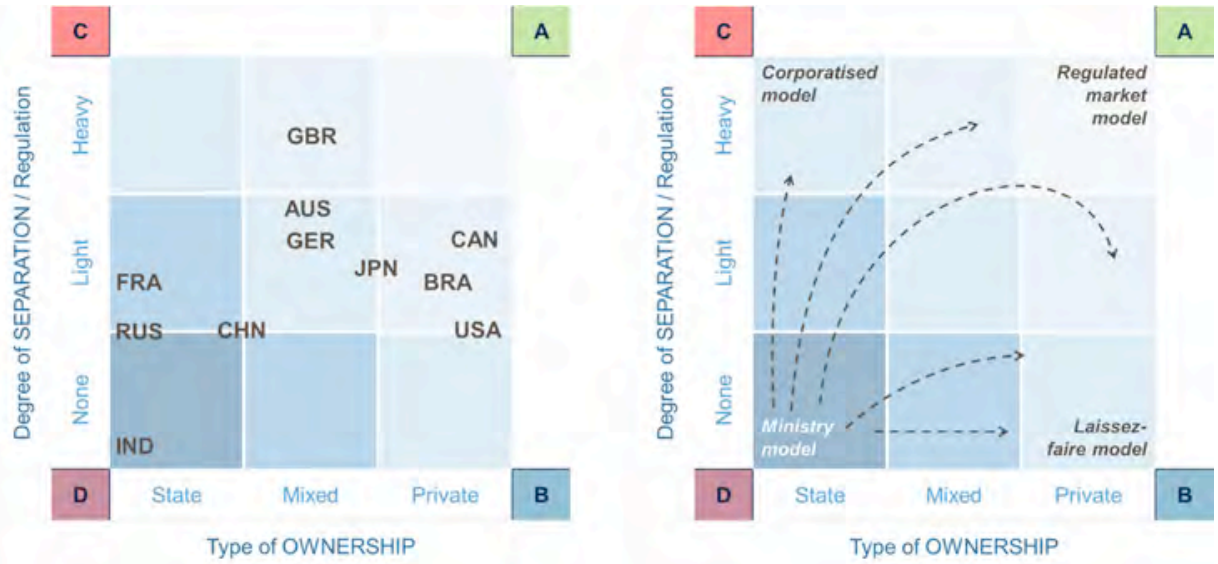

Figure 19.13 Rail Sector Models for 10 Comparator Countries and Possible Pathways for China 
This framework provides a three-by-three matrix for comparing rail sector models between comparator countries, and how they have changed since their networks were first built. The four corners of the matrix define four distinct models: the ministry model with state ownership and no separate, independent economic regulatory function; the corporatised model with state ownership but a separate economic regulatory function; the fully laissez-faire model with full private ownership and no economic regulatory oversight; and the regulated market model with full private ownership and an independent regulator endeavouring to ensure competitive or 'market' conditions prevail.

China, Russia and France have all moved away from the full ministry model, and among the comparator countries, only India remains in this part of the matrix. It is notable that among the 10 comparator countries, none of them occupies any of the other three corners of the matrix. The tendency is towards private or mixed state and private ownership, and towards light regulation.

There are no examples of a heavily regulated state-owned corporate rail sector. No examples of a regulated market model are found, due to the practical difficulties, even with independent regulatory oversight, of overcoming the natural monopoly characteristics of railways to create market competition. There is no full laissez-faire model in the rail sector (it could be argued that the pioneering entrepreneurs of railways in Britain operated under that model in the nineteenth century). The closest example is the United States, where private rail operators are lightly regulated and in the freight sector in particular are able to adjust prices to capture rent from coal producers.

Based on this analysis and the international experience of ownership and regulatory models, the dotted lines showing possible pathways for the future reform of China's rail sector all stop short of reaching the three corners of the matrix as reform 'destinations'.

\section{China's rail reforms and the challenges ahead}

\section{Overview}

On 14 March 2014, the Chinese Government began dismantling the MOR, folding its administrative functions into the Ministry of Transport and creating the CRC to carry out the former ministry's commercial functions. These changes were the latest phase of a reform process begun to repair the damage caused by a ten-year commitment to expand and upgrade China's rail system. 
In 2003 the MOR began a massive program of network expansion, including the construction of thousands of kilometres of high-speed rail track, to upgrade the country's passenger and freight transport systems. Figure 19.14 shows the 2020 network plan.

Years of aggressive rail construction led to an accumulation of some RMB2.8 trillion (US $\$ 459$ billion) in debt by the end of 2012 (Yan 2013). At the same time, the rail system was facing competition from the parallel build-out of the country's highway system (Figure 19.9), enabling the development of regional short and long-distance trucking fleets. Debt repayment obligations, low rail freight tariffs and insufficiently diversified passenger ticket pricing constrained system profitability well beyond the servicing capability of ordinary cash receipts, further compounding the problem.

The break-up of the old railway ministry is only the first milestone in the ongoing process of rail reform. Beyond sector restructuring, other aspects of the reform program include piloting a market-based ticket pricing system, a greater diversification of freight tariffs and the creation of a railway development fund to rationalise the financing of further rail expansion.

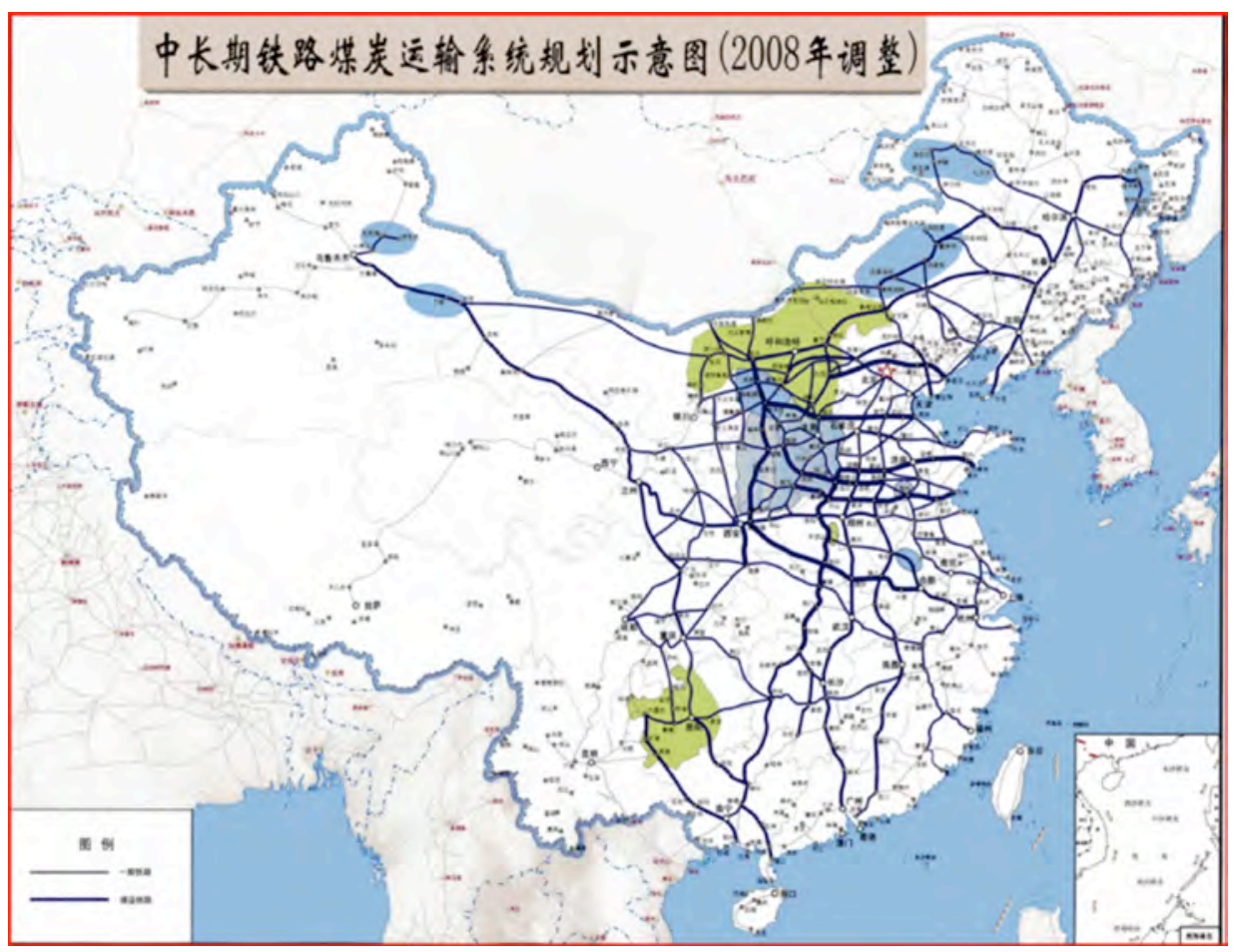

Figure 19.14 China's 2020 Rail Network Plan

Source: MOR (2008). 


\section{Constrained profitability}

China's rail system revenues are a function of passenger ticket and freight receipts, plus income from other diversified businesses. Although passenger and freight revenues grew steadily over the past 10 years, total profitability was poor due to a low average ticket price, an increasing debt-servicing burden and rising freight transport costs that offset improvements in the revenue stream.

The rail system has traditionally been operated as a public good, with a mandate to make sure the system is available to all income brackets and freight products. With particular regard to passenger fares, the rail system has been the primary form of long-distance transport for the low-income population and effort has been made to keep fares low. Hence passenger services have tended to be priced below their full economic cost.

At the same time, China's rail system remains one of the most densely trafficked in the world, with demand outstripping supply on many routes both for passengers and freight (Scales et al. 2011). The twin concerns of affordability and density mean that the rail system has not needed flexible pricing strategies, with the Government instead implementing a system of rail priorities that favours passengers during important holidays and coal and agricultural products at other times of the year. Further, until rail expansion began in 2003, regulated tariffs and ticket prices plus the railway construction surcharges provided adequate system revenue. It is only with the line expansions of the past decade that debt has begun to accumulate. Furthermore, with the completion of around $120000 \mathrm{~km}$ of track by 2020, the system managers will move from rationing capacity to selling it.

Finally, it must be noted that the complexity of application procedures for rail freight access, combined with long waiting times for wagons, and local issues associated with the loading and unloading of cargo have exerted a cumulative efficiency tax on revenues. Rent-seeking behaviour-sometimes legitimate and sometimes not-exerts a further cost for users and encourages the use of alternative transport methods such as trucking and, where available, inland waterway transport.

\section{Debt accumulation}

It should not be surprising that a rail capacity build-out of the scale in China over the past 11 years should be accompanied by a massive increase in debt. With the exception of the Government's RMB40 billion investment in the statefunded Qinghai-Tibet railway line, most railway construction since 1949 was funded by the MOR through a combination of fiscal funding, loans and bonds. Fiscal funding and construction surcharges accounted for some 70 per cent of 
total railway funding in 2004, dropping to 10 per cent by 2010 when loans and bonds provided some 60 per cent of funding requirements. Between 2005 and 2011, the railway sector accumulated about RMB500 billion in debt a year, much of which was funded by a combination of loans, bonds and even shortterm financing (Wu 2011). The RMB4.5 trillion in accumulated railway assets at the end of 2012 was equivalent to about 9 per cent of total GDP in that year. This left the rail system with RMB2.9 trillion in total debt - a debt-to-asset ratio of 62 per cent, and long-term debt making up 76 per cent of total liabilities.

The seriousness of the problem surfaced in the wake of the 2011 Wenzhou high-speed rail accident in Zhejiang Province, which killed 40 people and injured 192. The ensuing government investigation revealed shortcomings in both construction quality and financing arrangements on one of the most highly trafficked high-speed lines in the country. When the official report revealed the size of both debt and system operating losses, the State Council undertook measures to provide emergency loans and issue multi-sectoral governmentbacked bonds, as well as additional temporary subsidies to stabilise the railway system's financial situation while longer-term reforms were worked out.

\section{Reform and restructuring}

The Wenzhou accident investigation highlighted a fundamental structural problem within the railway ministry. Administrative, operational and commercial mandates were combined within one entity, with the day-to-day business of running the railway often confused by government administrative and regulatory functions. The dismissal and subsequent imprisonment of former railway minister Liu Zhijun in February 2011 also revealed that the apparent conflict of interest had provided a fertile breeding ground for corrupt activity.

At the March 2013 National People's Congress session it was announced that the State Council had decided to resolve this conflict by dissolving the MOR and moving policy and planning functions to the Ministry of Transport and Communications, and rail administration to the newly formed State Railway Administration (SRA). Meanwhile, all commercial and operational functions were folded into the newly formed China Railway Corporation (CRC), with the previous railway minister, Sheng Guangzu, appointed as its head.

In the context of the announcement, the Government also revealed that while the CRC would function as a commercial entity, it would report directly to the State Council. Furthermore, it would continue to fulfil the social obligation of the old ministry by implementing a government-backed rail-subsidy mechanism to ensure the continued discounting of fares for students and disabled passengers and freight rates for agricultural products. The $\mathrm{CRC}$ is also responsible for 
funding railway research and the operation of the Qinghai-Tibet line on behalf of the Government. The 18 regional rail bureaus and associated employment of roughly two million workers have been folded under the CRC's mandate.

The CRC's primary functions are passenger and freight transport, and the management and maintenance of the national rail network. The CRC also has responsibility for developing and implementing plans for sustainable railway construction investment funded from both public and private sources. Finally, the CRC has been given final accountability for rail safety.

The SRA is responsible for formulating railway technical standards, providing oversight of rail safety and service quality, and ensuring quality standards are met.

\section{Rail construction, private investment and reform}

One of the key questions for the newly formed CRC is how it will be able to finance planned rail construction targets. Given its status as a government office, the old MOR had little difficulty obtaining bank financing, but it is so far not clear how easy it will be for the CRC to obtain funds for planned projects. While Sheng Guangzu stated in 2013 that the Government would continue to offer financing for projects deemed necessary for social reasons, commercial projects would need to rely at least in part on private sector investment.

A diversified financing scheme was proposed several years ago as a potential solution to this problem and is being revisited now. Under such an arrangement, state-level players will continue to be responsible for main lines while private and foreign investment will be encouraged for feeder lines, with local governments taking the lead in land acquisition and resettlement. Given high entry costs and low returns, there has been little private sector interest so far, with the exception of a limited number of dedicated line projects.

A State Council document issued on 19 August 2013 intended to accelerate reform of railway investment and financing. The document revealed that private investors would be allowed to own and operate railway networks and services. In addition, it called for the establishment of a railway development fund to be financed by the Central Government. The document also called for the development of stations and land along railway lines as a means of improving investment revenue and stressed the need for market-based reform of freight tariffs while it supported a subsidy scheme for rail fares.

The reason for weak private sector interest is tied to subsidised constraints around passenger fares and freight charges. As Hu Shuli, editor of Caixin, argued in a recent editorial: 
$[\mathrm{P}]$ rivate investors will only enter the market when competition is introduced into rail network construction and train services, and when a mechanism is in place to adjust fares based on market conditions. In fact reform of the railway system shares something in common with reforms of other strategic industries such as electricity, telecoms, civil aviation and oil, which are mainly led by state enterprises. Reform in all of these sectors is a two-step process: first, separate government functions from enterprise management; second break up the monopoly by introducing competition. (Hu 2013)

\section{Debt management}

A consensus has arisen that the Government should develop a plan to relieve the CRC of the debt inherited from the MOR. Statistics from the National Audit Office indicate that the CRC carried RMB2.9 trillion in debt by June 2013, most of it inherited from the MOR. Most experts believe that a dividing line should be drawn between old and new rail debts, with the CRC responsible only for the debt it incurs. Wang Mengshu of Beijing Jiaotong University argues that the state should write off part of the CRC's total debt as non-performing bank loans, since a considerable portion of them were provided in the national interest (Qi and Yang 2014). Other proposals go further, urging that the MOR's old debt be separated from the CRC's portfolio and managed by a state-run assetmanagement entity similar to the State Asset Supervision and Administration Commission (SASAC) set up by the State Council to manage SOE debts.

Beyond the question of how to dispose of the MOR's old debts is the question of how the CRC should most effectively manage its own obligations. On the one hand, an increase in freight and passenger tariffs would be helpful, but on the other, the CRC is prevented from sharply increasing rates by its social obligation to keep the rail system affordable. Furthermore, the rail system has already lost market share to inter-regional trucking and bus fleets, which take advantage of China's new highway system to competitively move long-distance freight. Raising freight and passenger tariffs too much too quickly would undermine the system's competitiveness, causing further damage to its financial position.

According to Sheng Guangzu, the rail network's share of total freight volumes shrank from about 48 per cent in 1980 to 17 per cent in 2012. In contrast, road freight's market share rose to 35 per cent from only 6.4 per cent over the same period. Rail still captures the largest volume of raw material bulk transport but the trucking fleet is better able to efficiently ship components and finished goods, especially over shorter distances. 


\section{Rail tariff reform}

Notwithstanding the above concerns, an increase in rail freight tariffs is seen as the most direct means of reducing system debts. A joint project between Beijing Jiaotong University and the World Bank in 2013 indicated that the CRC would be able to pay off its debt within 10 years with an average freight rate of 13 cents/t/km, assuming average annual growth in railway freight and passenger volumes remained above 5 per cent.

In early 2013 the NDRC approved an increase in rail tariffs by an average of $1.5 \mathrm{c} / \mathrm{t}$. After the rail reforms were announced in late March, the CRC itself began to push for further reform of rail and passenger tariffs. Tariffs were raised on 14 February 2014 from the previous system-wide average of $12 \mathrm{c} / \mathrm{t} / \mathrm{km}$ to $15 \mathrm{c} / \mathrm{t} /$ $\mathrm{km}$. Besides helping to pay down debt, the increase in freight tariffs is expected to increase returns to potential private investors. A second step, to introduce a dynamic pricing system to better capture revenues on peak demand, is under consideration, though the details have yet to be fully worked out.

Some experts remain worried that the increase in rates will seriously damage rail freight's competitiveness, especially over short distances. Zhao Jian of Beijing Jiaotong University estimates that rail freight has lost its price competitiveness over distances of less than $1000 \mathrm{~km}$. Sun Zhang, a professor at the institute of railways and urban mass transit at Tongji University in Shanghai, argues that freight tariff increases should be selective and applied to routes dominated by bulk goods such as coal.

\section{Rail service reforms}

A further dimension to system competitiveness is the issue of service quality and efficiency. Even though rail freight charges may be on average lower than trucking charges at distances of more than $500 \mathrm{~km}$, the time required to apply and receive approval for rail freight access and then load and unload the goods may double the time it takes for a shipment to go through. In contrast, truck freight pick-ups can be arranged at only a short interval in advance and delivery can be made straight to the client, rather than having to be unloaded at the destination station and reloaded to make the final trip to the consumption point.

The CRC is moving to address these issues, announcing in June 2013 the launch of measures such as an express train service and door-to-door delivery. It is also looking at ways to simplify the application process with the introduction of an online booking system and telephone hotlines. 


\section{Conclusion}

The CRC is facing a series of conflicting challenges. It must pay down debt while continuing to pursue an aggressive build-out of track, particularly highspeed track for dedicated passenger services. Private investment is encouraged by revenue growth, but social obligations and related subsidies must be maintained. It must raise freight rates, while remaining competitive with trucking fleets and other alternative modes of transportation offering more flexible and door-todoor service. Service efficiency and quality must improve while the system remains the lowest cost and most environmentally sustainable transport option over long distances. The experience of other national rail systems suggests that, while there may be no perfect solution, gradual implementation of tariff reforms and efficiency improvements are essential to stabilising system economics.

Further restructuring of the rail sector is likely in coming years. Multiple options for further reform are under active debate and include: 1) preservation of the CRC's current near-monopoly to maximise system efficiency; 2) breaking the $\mathrm{CRC}$ up into regional enterprises to increase competition and pricing efficiency, perhaps via benchmark or yardstick regulation; and 3) separating passenger transport into a separate business distinct from freight transport to facilitate passenger subsidies while increasing the commercial competitiveness of freight. Though it is not yet clear which option will be selected, sector structure will be critical in determining the development path of the railway system and will drive other reforms such as pricing the degree of competitive and economic regulatory pressure.

China is in the early stages of the reform process of its rail sector. In no country in the world is the rail system as vital as it is in China to the movement of people, goods and energy. There is a variety of models around the world for the ownership, management and economic regulation of passenger and freight railways. As the review in this chapter shows, across China and 10 other major countries representing some 90 per cent of the world's rail transport, no two countries are exactly alike with respect to ownership and regulatory arrangements. The industry structure and regulation in each country reflect history, the stage of development and the general approach to public policy.

No one model of economic regulation of railways is perfect. International experience indicates that the introduction of 'perfect competition' is impossible in the rail sector. Care is needed in drawing analogies with other large, formerly state-owned sectors. For example, China's coal sector has been recently reformed such that prices are today largely determined by dynamic market forces. But although coal is transported via rail and road networks, and is supplied to a network-connected industry (electricity), coal is not itself a network industry, nor does it have natural monopoly characteristics. China's power sector, in 
contrast, was restructured a decade ago, but the Central Government nevertheless continues to set wholesale and retail electricity tariffs rather than use market competition to determine prices. The power system is a closer analogy to the rail system than is the coal sector. Like rail, power is a network industry with natural monopoly characteristics, at least in transmission and distribution. Like railways, the power system has stringent technical requirements for its safe and reliable operation. Like railways, the power system can also be considered to have strong public good characteristics, as the economic cost of a single widespread supply disruption or service interruption event tends to be orders of magnitude larger than the economic gains from continuous efficiency improvements.

China is likely to continue to set prices for both passenger and freight transport in the rail sector through a regulatory process that takes into account wider economic and social considerations.

\section{References}

Amos, P and Bullock, R (2011), Governance and structure of the railway industry: three pillars, China Transport Topics No. 2, December, The World Bank, Beijing.

Bullock, R, Salzberg, A and Jin, Y (2012), High-speed rail-the first three years: taking the pulse of China's emerging program, February, China Transport Topics No. 4, The World Bank, Beijing.

China Coal Transport and Sale Society (CCTSS) (2014), Database 2014, Beijing: China Coal Transport and Sale Society. Available from <http://www.cctd. com.cn>.

Economic Research Centre (ERC) (1995), China Investment Strategies for China's Coal and Electricity Delivery System, Beijing: The World Bank.

Fenwei/Shanxi Coal (2014), China Coal Weekly, Newsletter and database, Shanxi: Fenwei Energy Consulting Company Limited. Available from <http://www. sxcoal.com $>$.

Hu, S. (2013), 'Spur competition and ease back on controls to keep rail reform on track', South China Morning Post, Insight and Opinion, 19 September, provided by Caixin Media, [also published in Chinese in Century Weekly].

Ministry of Railways (2008), Map. Available from < http://bbs.railcn.net>. 
Ministry of Transport (2008a), Long-Term Railway Development Plan, Beijing: Ministry of Transport.

Ministry of Transport (2008b), Mid-Term Railway Development Plan, Beijing: Ministry of Transport.

Muzutani, F. and Nakamura, K. (2004), The Japanese Experience with Railway Restructuring, Cambridge, Mass.: National Bureau of Economic Research.

National Bureau of Statistics (NBS) (2012), China Statistical Yearbook, Beijing: China Statistics Press.

Organisation for Economic Cooperation and Development (OECD) (1997), Railways: Structure, Regulation and Competition Policy, Policy Roundtables, Paris: OECD.

Organisation for Economic Cooperation and Development (OECD) (2005), Structural Reform in the Rail, Policy Roundtables, Paris: OECD.

Organisation for Economic Cooperation and Development (OECD) (2013), Recent Development in Rail Transportation Services, Policy Roundtables, Paris: OECD.

Qi, Z. and J. Yang (2014), 'China implements radical railway reform', International Railway Journal.

Scales, J., Olivier, G. and Amos, P. (2011), Railway price regulation in China: time for a rethink?, China Transport Topics No. 1, December, The World Bank, Beijing.

Scales, J., Sondhi, J., and Amos, P. (2012), Fast and focused-building China's railways, China Transport Topics No. 3, February, The World Bank, Beijing.

Stanley, T. and Ritacca, R. (2013), All Aboard: High-Speed Rail Network Connecting China, China 360, KPMG Global China Practice.

Wang, P., Yang, N. and Quintero, J. (2012), China: the environmental challenge of railway development, China Transport Topics No. 6, June, The World Bank, Beijing.

Williams, R., Grieg, D. and Wallis, I. (n.d.), Results of railway privatization in Australia and New Zealand, Transport Papers, The World Bank, Washington, DC.

World Bank (2013), Database 2013, Washington, DC: The World Bank. Available from < http://data.worldbank.org/>. 
Deepening Reform for China's Long-Term Growth and Development

Wu, J. (2011), China's Railway Debt Crisis Accelerates Reform, Beijing: Beijing Jiaotong University.

Yan, P. (2013), The Challenges and Opportunities of China Railway's Marketization, New York: Dragon Gate Investment Partners. 
This text taken from Deepening reform for China's long-term growth and development, edited by Ligang Song, Ross Garnaut, Cai Fang, published July 2014 by ANU Press, The Australian National University, Canberra, Australia. 